\title{
DIGITAL CINEMA: AN ALTERNATIVE MODEL FOR POST-APARTHEID CINEMATIC PRODUCTION AND CONSUMPTION?
}

Astrid Treffry-Goatley

University of KwaZulu-Natal

\begin{abstract}
Patterns of cinematic production and consumption are often symptomatic of wider politico-economic and socio-cultural forces. This is the case in South Africa, where this site of cultural production, like the society as a whole, is marked by severe racial stratification and division. One finds, for example, that as a direct result of apartheid inequality, the majority of the population has been alienated from the mechanisms of cinematic production and consumption. This fragmentation remains one of the greatest challenges to the sustainability and racial transformation of the post-apartheid film industry. In this article I present a critical discussion on the rise of the low-budget, digital film in South Africa. With careful reference to prevailing politico-economic conditions and available state-support measures I analyse the potential of digital technology to revolutionise cinematic production and consumption practices. In analysis, it was found that while cinema has indeed become somewhat more accessible, the production, distribution and exhibition of motion pictures in
\end{abstract}


South Africa remain monopolised, exclusive and inaccessible to the majority. Moreover, it is questionable whether the digitised consumption mechanisms in place penetrate a wide enough market to sustain the movement. Therefore, although this is indeed an exciting movement in the industry, it should not be viewed as an outright replacement of existing technology nor a means for independent filmmakers to make it alone. On the contrary, it is most likely to run parallel to existing entertainment mechanisms and state support will still be required to encourage diversity and encourage sustainability.

\section{Introduction}

Patterns of cinematic production and consumption are often symptomatic of wider politico-economic and socio-cultural forces. This is the case in South Africa, where this site of cultural production, like the society as a whole, is marked by severe racial stratification and division. One finds, for example, that as a direct result of apartheid inequality, the majority of the population has been alienated from the mechanisms of cinematic production and consumption. This fragmentation remains one of the greatest challenges to the sustainability and racial transformation of the post-apartheid film industry. The research presented in this article is part of a larger $\mathrm{PhD}$ study that I conducted at the University of Cape Town under the supervision of Associate Professor Martin Botha on the representation of national identity in the production of post-apartheid feature films. Research took place between 2007 and 2009 and incorporated both quantitative and qualitative methodologies. The qualitative research component comprised over forty qualitative interviews with filmmakers and film professionals in Johannesburg, Durban and Cape Town over a two-year time frame. In this article I present a critical discussion on the rise of the low-budget, digital film in South Africa. With careful reference to 
prevailing politico-economic conditions, available state-support measures and a business criteria recommended for the establishment of an alternative narrative cinema by Irwin, I analyse the potential of digital technology to revolutionise post-apartheid cinematic production and consumption practices (5-6).

\section{Background}

Between 1948 and 1994, the Nationalist Party instituted a system of segregated racism in South Africa known as apartheid. ${ }^{1}$ This complex legal structure was designed to advance white interests at the expense of the black majority, who were subject to violent oppression and exploitation. ${ }^{2}$ During this period, the country's cinema was known to the world as the 'Cinema of Apartheid' (Ukadike 573). This cinema of propaganda, censorship and oppression catered almost exclusively for the white population with very few black filmmakers being empowered to participate in cinematic production or consumption. An example of apartheid's impact on cinema is the Group Areas Act of 1950, which prohibited black people from entering the economically privileged 'white areas' without prearranged, official consent, ${ }^{3}$ however, cinematic infrastructure in the 'black areas' was extremely scarce and thus the majority of the population was effectively alienated from cinema. Cinema under apartheid was also subject to severe industry monopolisation. For example, national distribution and exhibition networks were controlled by a handful of companies that had longstanding, often exclusive agreements with the major Hollywood studio. These circumstances have resulted in a very small national cinema-going audience (approximately eleven percent of the population) that is accustomed to Hollywood-style entertainment. This audience remains one of the greatest problems challenging the sustainability and equality of the post-apartheid film industry. 
In 1994, South Africa made international history when the backward, racially segregated apartheid state was finally overthrown and the country became a democracy. Under the leadership of former-activist Nelson Mandela, the African National Congress (ANC) stepped into this celebratory atmosphere and took on the task of making the South African 'miracle' of peaceful transformation a continuous reality. However, more than four hundred years of colonial rule and forty-six years of apartheid had resulted in a severely divided society with little sense of national identity or togetherness. In 1996, a new National Constitution was released. This charter envisioned a progressive society, emphasising: equality, multiculturalism, reconciliation and freedom. However, the transformation that it envisaged was not possible without the application of a people's imagination (Saks 132). Thus, expressive forms such as cinema were arrested to assist in the 'refashioning of personal and collective identities and in the rediscovery of a common humanity' (Barber 177). Therefore, after 1994 the state introduced numerous strategies and initiatives to boost the growth of the national film industry. Such measures have been framed within the prevailing national politico-economic paradigm. For example, in 2004, the government prioritised the growth of creative industries under the Accelerated and Shared Growth Initiative (Department of Trade and Industry 4). This emphasis on growth can be linked to the neoliberalism of the 'Growth, Employment and Redistribution' (GEAR) development policy that was introduced by the ANC in 1996. GEAR was preceded by the Reconstruction and Development Programme (RDP), a macroeconomic policy that favoured a pluralistic and participatory form of governance and supported reconstruction and redistribution before economic growth (Mhone 21). 
The shift from RDP to GEAR can be seen as evidence of the conflicting interests within the ANC, which, since inception, has incorporated a variety of members with somewhat incompatible sentiments (Tomaselli and Teer Tomaselli 176). It can also be related to South Africa's status as a developing country in the globalised world since neoliberalism is essentially a formula that has been adopted by the 'main international agencies [the World Bank and the International Monetary Fund (IMF)] charged with the task of helping developing countries get on the high road to greater prosperity' (Sparks 208). For example, in the case of South Africa, after his release, Mandela shifted from a firm belief in the nationalisation of resources for the people (as the Afrikaners had done under apartheid for 'their people') to a policy of privatisation, which was more in line with global development standards (Sparks 171-6). While a robust economic strategy might indeed have been required to support the radical transformations in South African society, this rather rigid formula is sometimes at odds with the New South African vision of diversity, equality and freedom and has resulted in tensions and contradictions between different aspects of state policy. This is evident in the White Paper on Film of 1996, a key document in industry development, which can be seen to combine the somewhat contradictory 'fighting rhetoric one has come to associate with postcolonial academese with phrases that might be found in a reader on economic policy' (Saks 141). ${ }^{4}$ These contradictions and neoliberal emphases can be seen to pose a threat to the transformation and sustainability of the film industry because a free-market paradigm supportive of competition and market led growth seldom encourages the direct state intervention that is needed to build a democratic culture of filmmaking and film viewing in South Africa. 


\section{State support for digital filmmaking}

The lowering of production budgets has been made possible through advances in digital technology. These advancements have allowed for the development of improved, high-definition (HD) production quality and innovative storage, distribution and consumption solutions. Affordable modes of film production and distribution have been welcomed by many filmmakers in South Africa due to the poor performance of local films on national and international circuits. In a recent article on the post-apartheid film industry, Flanery highlighted this crisis when he questioned why South African cinematic products are "so often either aesthetic, narrative, critical or commercial failures, both within South Africa and in the global marketplace and mediascape?" (239). Statistics released in a recent National Film and Video Foundation (NFVF) Report highlight this failure: "fifty percent of the feature films produced in the period 2000-2007 failed to recoup ten percent of the production cost at the local box office" (NFVF a 25). Nevertheless, there have also been some important successes in the post-apartheid film industry that deserve mention. Firstly, one cannot ignore the commercial success of the service sector of the industry. This sector provides logistical and technical support for 'runaway' productions and earns in excess of R2.2 billion per annum (Silinda 25). Secondly, postapartheid films have accomplished certain aesthetic achievements, winning some significant awards at prestigious international film festivals. These include a Grand Prix at Vues d'Afrique, Montreal for Chiken Biznis-the Whole Story (Wa Luruli, 1998), the nomination of an Oscar for Best Foreign Feature for Yesterday (Roodt, 2004), an Etalon de Yennenga at FESPACO for Drum (Maseko, 2004), a Golden Bear at the Berlin Festival for UCarmen eKhayelitsha (Dornford-May, 2005) and an Oscar for Best Foreign Language 
Film for Tsotsi (Hood, 2006). Thus, if one defines 'success' as the receipt of prestigious awards at international film festivals, then the South African film industry might be described as 'flourishing' (Dovey 144). Thirdly, if one analyses box office sales over time (refer to Table 1), it is evident that ticket sales are improving, with 2008 being the most profitable of all years (1994-2008). The success of the service sector and the potential profitability of the local sector has encouraged the state to invest in infrastructure to stimulate growth and increase the competitiveness of the industry. There are three key state support structures available to the post-apartheid filmmaker. These are The Industrial Development Corporation of South Africa (IDC), the National Film and Video Foundation (NFVF) and the Department of Trade and Industry (DTI). Below I briefly discuss the role of these three structures with particular emphasis on their respective influence on the development of low-budget filmmaking post-apartheid.

\begin{tabular}{|l|l|}
\hline Year & Local Box Office \\
\hline 1994 & $8,223,619.00$ \\
\hline 1995 & $2,009,491.00$ \\
\hline 1996 & $16,362,292.00$ \\
\hline 1997 & $2,524,857.00$ \\
\hline 1998 & $3,549,494.00$ \\
\hline 1999 & $11,981,786.00$ \\
\hline 2000 & 0.00 \\
\hline 2001 & $33,167,556.00$ \\
\hline 2002 & $348,432.00$ \\
\hline 2003 & $2,362,060.00$ \\
\hline
\end{tabular}




\begin{tabular}{|l|l|}
\hline 2004 & $25,984,554.00$ \\
\hline 2005 & $31,915,766.00$ \\
\hline 2006 & $15,424,709.00$ \\
\hline 2007 & $3,943,241.95$ \\
\hline 2008 & $46,149,064.00$ \\
\hline
\end{tabular}

Table 1: Box Office by Annum

The IDC is a self-financing, National Development Finance Institution (DFI) that was established in 1940 to promote the economic growth and industrial development of the country (IDC). Under the auspices of the Department of Trade and Industry (DTI), and management of the Media and Motion Pictures Division, it is one of the biggest investors in the film industry. Since 2001, it has funded over thirty films to the value of over R500 million (62.5 million dollars) (Silinda 25). Nevertheless, despite the substantial amount of money invested, few local, in particular low-budget, films have benefited from this support. The fact is that the rather stringent conditions attached to this finance have had a great impact on the types of films that have successfully applied. Firstly, the funds provided come in the form of a repayable loan and therefore not only are the filmmakers obligated to repay the investor with interest, but in order to protect their investment, the IDC tends to be rather conservative and commercially orientated in their selection of products (IDC 5). For example, preference is given to filmmakers with a 'track record' of commercially-successful filmmaking (Ibid.). However, this excludes many local filmmakers in particular black/previously-disadvantaged filmmakers who have limited experience in this field. IDC policy also places emphasis on the accession of wider markets through 'highprofile' distributors (Ibid.). However, local filmmakers encounter 
high entry barriers to the foreign market due to the increased levels of merger activity and a concentration of ownership' in the global film industry and thus, this is an added factor that makes this form of finance inaccessible to the local filmmaker (Tuomi 82). Therefore, the films that are more suited to this form of finance large budget international coproduction and foreign productions that feature internationally recognised directors, producers and foreign stars [Blood Diamond (Zwick 2006), In My Country (Boorman, 2004) and Goodbye Bafana (August, 2007) are some examples]. In the DTI development strategy for the film and television sector, this trend is noted: 'The IDC being a commercial operation do not invest in many local productions rather in international productions or coproduction' (DTI a 17).

Co-productions are popular internationally as national industries struggle 'to produce, exhibit and distribute films in an environment dominated by Hollywood product' (Goldsmith and O'Regan 19). These production models are essentially financial arrangements whereby a film's budget is split between two or more international partners. International co-productions can be divided into official and unofficial agreements. Official co-productions are bound by an international treaty that is signed by representatives of the participating national governments. Such treaties strictly stipulate which languages can be used in production, who can participate, where the films are to be made, how the films are to be distributed, the ownership of the resultant intellectual property and the negotiation of artistic and editorial control, with the level of this control ostensibly being dependent on the financial contribution made by the participating countries (South Africa and Germany Treaty, Article 4, Clause 3 for example). Unofficial co-productions, on the other hand, are productions that also have shared international 
finance but are far less formal since they are not bound by official agreements.

Co-productions are a significant trend in the post-apartheid film industry with thirty-three percent of the films analysed between 1994 and 2009 being of this nature. Most of the co-productions in South Africa are made through unofficial co-finance agreements between South African filmmakers and ostensibly American or British producers and financiers. These productions accounted for eighty-nine percent of the co-productions within the period of analysis. State support for co-productions is evident at a number of levels. Firstly, there are the official co-production treaties that have been signed with Canada (1997), Germany (2004), Italy (2003) and the United Kingdom (2007) (NFVFa, 8). Secondly, South Africa has been sold internationally as the 'Co-production Partner of Choice' by the NFVF at international film festivals such as Cannes (Screen Africa). Thirdly, such productions receive significant production support from the state through the IDC, the DTI (discussed below) and the NFVF, with forty percent of the projects funded by the NFVF to date being co-productions. The reasons behind the state's support are multiple, and can be seen to relate to South Africa's position as a vulnerable, 'developing nation' in the global marketplace. For example, co-productions are often sold to the public as a way to (1) share production finance, (2) attract foreign currency, (3) access wider markets and (4) improve local filmmaking skills through working with more-experienced co-production partners.

While these benefits may indeed be real, there are also a number of other, arguably 'less positive' co-production trends that deserve mention. Firstly, the typical committee-style of filmmaking associated with this model tends to result in a fair degree of creative compromise. Furthermore, this production model has economic consequences. 
For example, in the Brazilian industry, co-productions, which were 'invented as a kind of salvation for Brazilian cinema, resulted only in an absurd cost increase for all cinematic production in Brazil' (Johnson and Stam 65). Furthermore, in the French industry, such productions have been estimated to use three times more state finance than local productions (Hayward 49). A similar trend is evident in South Africa, where co-productions are clearly more expensive to produce than local films. Table 2 below presents a budget scale of one to six that I devised to categorise and analyse the productions under study. In analysis, I found that while categories one and two were used exclusively by local productions, co-productions were clearly predominant in the higher budget categories, accounting for fiftyseven percent of the films in category four, fifty percent of category five (with the other fifty percent being productions featuring the local star Leon Schuster) and one hundred percent of category six. ${ }^{5}$

\begin{tabular}{|l|l|l|}
\hline Budget Category & Total Box Office & Average Box Office \\
\hline $\mathbf{1}(\mathbf{0}-\mathrm{R} 1 \mathrm{mil})$ & $336,218.00$ & $168,109.00$ \\
\hline $\mathbf{2}(\mathrm{R} 1-3 \mathbf{m i l})$ & $6,972,699.95$ & $996,099.99$ \\
\hline $\mathbf{3}(\mathrm{R3}-\mathrm{R} 10 \mathrm{mil})$ & $7,917,558.00$ & $989,694.75$ \\
\hline $\mathbf{4}(\mathrm{R} 10-\mathrm{R} 20 \mathrm{mil})$ & $8,538,358.00$ & $1,219,765.43$ \\
\hline $\mathbf{5}(\mathbf{R 2 0}-\mathrm{R} 50 \mathrm{mil})$ & $127,595,499.00$ & $12,759,549.90$ \\
\hline $\mathbf{6}(\mathrm{R} 50+)$ & $6,136,399.00$ & $2,045,466.33$ \\
\hline Total: & $\mathbf{1 5 7 , 4 9 6 , 7 3 1 . 9 5}$ & $\mathbf{4 , 2 5 6 , 6 6 8 . 4 3}$ \\
\hline
\end{tabular}

Table 2: Box Office and Budget Bands

It is questionable, however, whether the emphasis on highbudget, foreign productions in state policy is well-founded. In fact, this has attracted certain criticism. For example, an informant in the DTI Sector Development Strategy of 2005, argued that if the IDC 
had spent just ten percent of their total financing allocated to date on fifty percent finance for local films then approximately twenty South African films might have been made (DTIa 17.). This 'would have a greater impact in building the domestic industry and would probably have seen no worse returns than the aggregate experienced across the IDC slate to date' (Ibid). If one analyses local box office figures against the budget bands presented in Table 2 above, one can see that the local returns on high budget productions, particularly budget band six, are not very high. Furthermore, while category five does indeed appear to be more successful, if one considers that ninetytwo percent of the total box office for this band was made by four Leon Schuster productions, one can assume that such figures are an indicator of his local popularity rather than a general box office trend for this budget band. In fact, if one looks at the profit margins, one will see that budget band two is a less risky production option for local filmmakers. ${ }^{6}$

Although the IDC plays a significant role in the film industry, it is the NFVF, a non-profit organisation established in 1997 through Act 73 of Parliament, which is the principle mechanism for state assistance. The NFVF administers state aid for

various aspects of film production, distribution, exhibition and training, archives, management, research and information, visual literacy programs and the promotion of locally produced film and video both internally and abroad (Saks 133).

In 2005, the NFVF published a Value Charter. This document is based on the White Paper of 1996 and serves as a blueprint for postapartheid film industry development. Its vision is a 
film and video industry that mirrors and represents the nation, sustains commercial viability, encourages development and provides a medium through which the creative and technical talents of South Africans are able to reach the world (NFVFa 3).

Here one can identity multiple strains of "interest" with the words "mirrors and represents the nation" linking to the democratic ideals of the Constitution of 1996, while the emphasis on commercial viability and local talents reaching 'the world' being linked to the export-driven growth of neoliberalism and GEAR. The word "quality" in this vision is also significant since it is indicative of an emphasis on technical quality which is a trend in the post-apartheid film industry (Dovey 144). While this emphasis on technical quality could be seen as an attempt to maintain internationally recognised standards, and to garner support from international audiences and funding organs, Dovey rightly observes that this feature does not come without certain ideological compromises and that it places South African cinema in diametric opposition in its aims "to the producers and directors of the video film industries sprouting up in West Africa and East Africa" (146). Therefore, this emphasis might be seen as an obstacle to the development of a low-budget filmmaking model since these films might not be able to meet the same standard of technical quality as their high-budget counterparts. Nevertheless, in 2009, the NFVF updated their vision in the 2009 Value Charter and there is evidence in this Charter that suggests that the original stress placed on quality is fading and that low-budget films might enjoy more support from the state in the future.

The NFVF's updated vision is most interesting and bears a complex relationship to the development of the industry as a whole and in particular to the work of the NFVF. The vision publicised in the Charter of 2009 is a South African Electronic Content Industries (SAECI) that: 
- Mirror and represent the diverse national identities, particularly the previously marginalised.

- Promote the creative and technical talents of South Africans to find support in the pursuit of freedom of expression.

- Sustain viable livelihoods for those South Africans who choose this domain as their area of occupation.

- Entertain, educate and inform South Africans, the region, the continent and the world (NFVF b 8).

First it is important to note that the word 'quality' discussed above has been removed from the vision. Secondly, renaming the 'film industry' the 'Electronic Content Industries' is a key change in this Charter since it is indicative of the NFVF's intention to work within the realm of digital technology and of its belief that in the digital age, it is no longer viable to 'define the role of an institution in technology specific terms, such as film and video' (NFVF 25). Thirdly, as is evident in the second point of the vision, importance has been placed on the representation of previously marginalized people. However, as was mentioned above, cinema remains an exclusive, white-dominated domain and thus the inclusion of the majority in this site of cultural production will require major transformation. Perhaps digital cinema can be a major component of this change. Thirdly, the Charter is revolutionary not only in its overt recognition of the impact of monopolisation on industry development, but also in its suggestion that interventionalist measures such as a levy on cinema tickets and DVD sales' (NFVF 6), be used to assist industry growth. Such words are indicative of a shift in the industry away from a strictly 'free market' approach to development, towards one that is responsive to the influences of monopolisation and globalisation.

A further important aspect of this updated Charter is the implicit reference to freedom of expression in point two. This might be seen as 
a direct reference to the National Constitution, Chapter Two, Section 16, which grants all citizens the right to free expression. Perhaps a low-budget digital filmmaking model can serve this national right since a smaller budget is likely to reduce outside control from funders and collaborators and should allow a filmmaker greater freedom in creative expression and experimentation. In conclusion, this 2009 vision is most interesting since it suggests that there are fundamental shifts occurring in the post-apartheid film industry. However, since it is very new, it is not yet possible to assess its material outcomes. Furthermore, while the NFVF claims that it intends to incorporate the previously marginalised majority and to challenge the US dominated, monopolised industry, no clear plan of action or projects are outlined in the Charter, with the document remaining rather vague in this regard. Nevertheless, to date the NFVF has shown certain support for low-budget filmmaking and perhaps such measures will increase as the 2009 vision comes into action. For example, the NFVF is one of the state entities that has shown significant support for DV8 productions, a pioneering digital filmmaking company in South Africa that literally 'deviates' from traditional production and distribution measures.' NFVF support is further evident in the 3-film production slate awarded to RogueStar Films in 2008. However, although the NFVF has shown certain material support for low-budget filmmaking, it is the DTI, through their revised rebate of 2008, which has made the greatest impact to date.

The DTI's key mechanism for assistance in the film industry is the rebate scheme that was first introduced in 2004. According to this scheme, the state refunds filmmakers a fixed percentage of the funds spent on a production [or the Qualifying South African Production Expenditure (QSAPE) as it is officially known]. In 2008, the programme underwent some major revisions, with the 
adjustments in policy being indicative of the DTI's intention to grow the film industry by promoting smaller production budgets in both the service and the local sector. For example, when the rebate was originally launched, it was specifically created to meet the needs of high-budget productions. It was tailored at the export market and aimed to contribute 'significantly to making South Africa a preferred destination of choice for international film development as well as enhance the competitiveness of locally produced films on the global market' (DTI b). The export orientation of the original initiative is also identifiable in the prerequisite QSAPE of R25 million to qualify for the fifteen percent rebate. In 2008, after a consultative process with industry stakeholders, the DTI launched the new rebate system. The aims of this rebate are to create employment, increase local content generation and to improve the location competitiveness for filming in South Africa (DTI b). The revised scheme has two parts with foreign productions and South African productions (and official co-productions) receiving differential benefits. The first part of the scheme, the Location Film and Television Production Incentive, caters exclusively for foreign productions. Here the original minimum production spend of R25 million (3.1 million dollars) was lowered to R12 million (1.5 million dollars) (DTI b). The second part of the scheme, the South African Film and Television Production and Co-Production Incentive, is targeted at local productions and official, treaty co-productions with a rebate of thirty-five percent being given for the first R6 million spent, and twenty-five percent thereafter. The original minimum production spend of R25 million (3.1 million dollars) was radically lowered to R2.5 million (312,000 dollars) to accommodate low budget productions. From the Tables 3 and 4 below, it is clear the new rebate has been most successful in boosting local film production with the number of films and the 
average rebate having increased considerably in this relatively short time period. The average number of co-productions and foreign films has also increased due to this revised rebate.

\begin{tabular}{|l|l|l|l|l|l|l|}
\hline \multicolumn{2}{|l|}{ OLD REBATE: 42 Months (Jun 2004-Jan 2008) } \\
\hline $\begin{array}{l}\text { Prod. } \\
\text { Ap- } \\
\text { proved }\end{array}$ & No. & QSAPE & Rebate & Avg. QSAPE & $\begin{array}{l}\text { Avg. } \\
\text { per } \\
\text { month }\end{array}$ & $\begin{array}{l}\text { Avg. } \\
\text { re- } \\
\text { bate }\end{array}$ \\
\hline Local & 16 & $746,000,000.00$ & $140,000,000.00$ & $46,625,000.00$ & 0.4 & $19 \%$ \\
\hline Co-prod. & 7 & $272,000,000.00$ & $65,000,000.00$ & $38,857,142.86$ & 0.2 & $24 \%$ \\
\hline Foreign & 26 & $1,426,000,000.00$ & $166,000,000.00$ & $54,846,153.85$ & 0.6 & $12 \%$ \\
\hline TOTAL & $\mathbf{4 9}$ & $\mathbf{2 , 4 4 4 , 0 0 0 , 0 0 0 . 0 0}$ & $\mathbf{3 7 1 , 0 0 0 , 0 0 0 . 0 0}$ & $\mathbf{4 9 , 8 7 7 , 5 5 1 . 0 2}$ & $\mathbf{1 . 2}$ & $\mathbf{1 5 \%}$ \\
\hline
\end{tabular}

Table 3: DTI 2004 Rebate

\begin{tabular}{|l|l|l|l|l|l|l|}
\hline \multicolumn{2}{|l|}{ NEW REBATE: 19 Months (Feb 2008- August 2009) } \\
\hline $\begin{array}{l}\text { Prod. } \\
\text { Ap- } \\
\text { proved }\end{array}$ & No. & QSAPE & Rebate & Avg. QSAPE & $\begin{array}{l}\text { Avg. } \\
\text { per } \\
\text { month }\end{array}$ & $\begin{array}{l}\text { Avg. } \\
\text { re- } \\
\text { bate }\end{array}$ \\
\hline Local & 41 & $708,000,000.00$ & $143,000,000.00$ & $17,268,292.68$ & 2 & $20 \%$ \\
\hline Co-prod. & 12 & $265,000,000.00$ & $71,000,000.00$ & $22,083,333.33$ & 0.6 & $27 \%$ \\
\hline Foreign & 24 & $1,227,000,000.00$ & $154,000,000.00$ & $51,125,000.00$ & 1.2 & $13 \%$ \\
\hline TOTAL & $\mathbf{7 7}$ & $\mathbf{2 , 2 0 0 , 0 0 0 , 0 0 0 . 0 0}$ & $\mathbf{3 6 8 , 0 0 0 , 0 0 0 . 0 0}$ & $\mathbf{2 8 , 5 7 1 , 4 2 8 . 5 7}$ & $\mathbf{4}$ & $\mathbf{1 7 \%}$ \\
\hline
\end{tabular}

Table 4: DTI 2008 Rebate

\section{Low-budget filmmaking in a post-apartheid context}

Therefore, through the NFVF and the DTI, the South African state has offered certain support for the lowering of production budgets in the post-apartheid film industry. This support, together with the fact that many local filmmakers have been able to fund these productions privately, has led to a steady growth in the number of low-budget productions in the film industry. For example, in Table 5 below, it clear that since 2004, productions made on a budget 
of under R10 million (budget categories 1, 2 and 3) have become a common feature of the local industry. This trend reached a peak in 2007, when such categories accounted for eighty-six percent of the films under analysis. The dip in low-budget releases in 2008 (fiftyseven percent) is likely to be evidence of filmmakers' anticipation of the release of the significantly delayed revised DTI rebate. However, given the generous support of this scheme, one can expect the production of low-budget films to grow from 2009 onwards. This move towards a low-budget model for local filmmaking is indicative of a shift in focus in the industry. From a high-budget export driven model to more of a multilayered model that targets both export and local markets. In this latter model one finds that while the high value productions of an 'international standard' are still supported by the state, particularly through the DTI and IDC incentives described above, a low-budget trend, which is almost exclusively, or at least primarily, focused on the tastes and preferences of the local market, runs parallel. Because budgets are not high, the filmmaker is not under the same pressure to create products with mass appeal. Therefore, films can be made with the intention of appealing "first to audiences at home before [attempting to] break into foreign markets" (Mbalo 3). Therefore, this technology can have a major impact on the post-apartheid film industry.

\begin{tabular}{|c|c|c|c|c|c|c|c|c|c|c|c|}
\hline & & 2001 & 2002 & 2003 & 2004 & 2005 & 2006 & 2007 & 2008 & $\mathrm{~N}$ & $\%$ \\
\hline \multirow{6}{*}{ 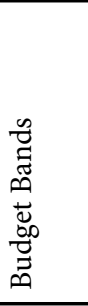 } & 1 (0-1mil) & 0 & 0 & 1 & 0 & 0 & 0 & 1 & 0 & 2 & 4.76 \\
\hline & 2 (1-3mil) & 0 & 0 & 0 & 0 & 3 & 0 & 2 & 3 & 8 & 19.04 \\
\hline & 3(3-10mil) & 0 & 0 & 0 & 2 & 3 & 1 & 3 & 1 & 10 & 23.82 \\
\hline & $4(10-20 \mathrm{mil})$ & 1 & 0 & 0 & 0 & 2 & 2 & 1 & 1 & 7 & 16.66 \\
\hline & $5(20-50 \mathrm{mil})$ & 1 & 1 & 0 & 2 & 2 & 3 & 0 & 1 & 10 & 23.82 \\
\hline & $6(50 \mathrm{mil}+)$ & 0 & 0 & 1 & 1 & 1 & 1 & 0 & 1 & 5 & 11.90 \\
\hline Total & & 2 & 1 & 2 & 5 & 11 & 7 & 7 & 7 & 42 & 100 \\
\hline
\end{tabular}

Table 5: Budget Bands by Year 
Although mainstream industry can also profit on the lowbudget benefits of digital technology, Irwin has argued that the most radical potential lies with the independent filmmaker, for the first time "since the establishment of Los Angeles as the capital of the film industry", might find a viable, independent filmmaking model in reach (5-6). However, to sustain such a feature narrative practice, fundamental business requirements need to be met, and a supportive marketplace ought to be in place (Irwin 5). "Anything less condemns independent feature to a cultural ghettoization" (Ibid.). The four 'business' conditions that Irwin identified are summarised below:

1. The quality must meet industry standards and yet the costs should be low.

2. The means of distribution should be cost-effective and should enable filmmakers toreach out to the most appropriate audiences for their work.'

3. The audiences must be large and insatiable so that new material can also feed into the existing market.

4. There should be an 'opening in the market place' such as 'underserved niche audiences of significant size, or an unfulfilled need at the bottom of the market space' (Ibid).

In the following discussion, using these business conditions as a rough guide, I will outline the possible benefits and limitations of digital technology as a potential model for independent feature film production and consumption in the post-apartheid context. In terms of quality, while digital films can be seen to eliminate "jitter, weave, dirt, and scratches from the projected image" (Belton 107), there are still certain concerns regarding the quality of digital capture and projection. This depends, however, on the quality of the equipment used by the filmmaker and the distributor. For example, projecting 
a DVD to the big screen can result in an inferior pixilated image that would not meet current industry standards. Nevertheless, significant technological developments have been achieved with digital production and projection equipment, making digital films more and more suitable for mainstream digital distribution (without having to undergo the DI process mentioned above). In fact, since 2002, six major Hollywood Studios (Disney, Fox, Paramount, Sony Pictures Entertainment, Universal and Warner Bros.) under the Digital Cinema Initiative (DCI) have been conducting research to establish and "document specifications for an open architecture for Digital Cinema components that ensures a uniform and high level of technical performance, reliability and quality control" (DCI). This mainstream interest is indicative of the potential escape that the digital medium provides from Hollywood's risky, oft-unsuccessful high-budget approach to cinematic production (Irwin 7).

Digital filmmaking is becoming popular because although it might not be at the same quality level of as $35 \mathrm{~mm}$ film, it is indeed "a high-quality and low-cost means of production" (Irwin 4). The exact savings per production is dependent on the type of equipment utilised by the filmmaker. However, even when high-end HD cameras are used, which can, in fact, be rather expensive to rent, a filmmaker still saves by not having to purchase film, process it and telecine it (process of transferring motion picture film into video format). The savings on the 'lower end' of HD filmmaking are somewhat greater with camera rental being much cheaper and post-production costs also being reduced since filmmakers can edit and grade their films on a personal computer (with suitable software of course) rather than in an expensive, high end edit suite. One of the initial challenges of this production technology for filmmakers was the question of storage, since even "a modest 90-minute movie 
generates more than two terabytes (2 million megabytes) of data" (The Futurist 9). However, this is becoming less of an issue with the increased capacity and reduced cost of non-linear storage solutions (such as portable hard drives) and researchers finding ways to "store moving images in high quality-a requirement if digital cinema is to match the high standards demanded by audiences of the silver screen" (Ibid.).

In terms of the second requirement, in addition to facilitating a low-cost means of production, "digital marketing resources offer costeffective and powerful distribution channels" (Irwin 4). Such savings relate to the second business requirement of finding cost-effective ways of reaching audiences. For instance, on the distribution side, a filmmaker/distributor can make substantial savings by not having to make a $35 \mathrm{~mm}$ print of the film (this is known as Digital Intermediate (DI), and costs an estimated R1 million in South Africa). Nevertheless, if a film is destined for a mainstream, widespread release, since the number of digital screens is currently limited, then DI costs may still apply. A second saving relates to making print copies for release (at a cost of approximately R5 to 10 thousand per print in South Africa or $\$ 2000$ in the U.S). There are also transportation costs to be considered with satellite and/or online delivery making this technology a relatively cheap way of delivering film to theatre (Belton 105). Nevertheless, while such delivery mechanisms might work for the independent filmmaker, given the major threat of piracy in the industry, it is unlikely that major Hollywood studios will take this risk when transporting high-budget product (Belton 113). There are certain limitations, however, when it comes to accessing mainstream distribution/exhibition channels because although the move to digital is clearly welcomed by distributors, given the high cost of installing digital screens-estimated to be between $\$ 100$ and $\$ 180000$ in the 
US)-exhibitors are, understandably, far more cautious (Belton 111). Therefore, although digital cinemas are growing internationally, one cannot expect the digital screen be an outright replacement of the traditional $35 \mathrm{~mm}$ equipment.

While digital technology might have certain limitations when it comes to traditional exhibition, the possibilities for alternative consumption are quite wide. This potential relates specifically to the flexibility of digital media and its integration into a whole media network encompassing theatres, video and DVDs, thematic cable channels, satellite and digital television (Danan 181). This integration has led to an increasing percentage of a film's profits being made through such ancillary markets (Belton 107). Statistics available for the US market indicate that theatrical box office accounts for just twenty-six percent of a typical film's revenue. "Television sales bring in about $28 \%$, on average, and the video and DVD market accounts for a whopping 46\%" (Irvin 9). Such figures directly challenge the "popular but erroneous assumption that theatrical box office receipts are the dominant revenue of a film' and indicate that the video/DVD is driving the marketplace" (Ibid.). Thus, it can be assumed that despite the high piracy risk of the DVD format, home entertainment has become the true focus of Hollywood product with theatrical distribution being something of an 'expensive marketing campaign designed to eventually drive the sales of videos' (Ibid.). However, the potential of the DVD extends beyond the limits of the mainstream Hollywood studio, to the field of independent film distribution with digital channels offering such filmmakers a selection diverse, and innovative means to reach "out to the most appropriate audiences for their work" and also enable audiences to access such work (Irwin 5).

Thus, one might say that the first two business requirements can potentially be met through this digital production and distribution 
model. Nevertheless, it remains to be seen, in the South African context, whether this model can work. Are the relevant mechanisms in place to reach a wide audience? And, is there a suitable opening in the market place? In the discussion that follows I attempt to answer these questions. In doing so, I refer to a comparable low-budget model of Cinema Novo adopted by independent filmmakers in Brazil during the 1960s. Even if we take into consideration the time gap-as well as the access to lighter equipments in the present - one finds, that as in South Africa, in recognition of the inadequacy of a Hollywood-studio model for industry development (promoted in Brazil by the Vera Cruz studios, among others), Brazilian filmmakers adopted a new mode of cinematic development that favoured lower budgets. In this South American context, where commercial cinema was the norm, this auteur-driven movement became revolutionary (Johnson and Stam 64). The aesthetic adopted by this group, was one 'of hunger', which highlighted the independence and relative poverty of the productions through opting for an "independent and inexpensive mode of production using, initially, small crews, location shooting, and non-professional actors" (Johnson and Stam 363). Cinema Novo also revolutionised the understanding of cinema by adopting a critical, serious focus on Brazilian society, and by using cinema as a tool for change and social commentary rather than just as a medium for entertainment (Ibid.)

If one compares this movement to digital filmmaking in South Africa, one finds that there are some interesting points of comparison and convergence. For example, in addition to a similar low budget focus, a number of South African films have a relatively serious, critical view of post-apartheid society. In fact, between 2004 and 2005, such films (dramas) made up an estimated thirty-eight percent of the films produced for which budget information was available. Films 
of this description include: Forgiveness (Gabriel, 2004), that speaks about the process of forgiveness and redemption in post-apartheid South Africa, Yesterday (Roodt, 2004), a film that highlights the plight of HIV/AIDS infected individuals in rural South Africa, Boy Called Twist (Greene, 2004), a film about children who live on the streets of Cape Town, Faith's Corner (Roodt, 2005), a silent film that follows the struggle for survival of a mother and her two children living on the streets of Johannesburg and Soldiers of the Rock (Maake, 2005), a tale about the men who have built the wealth of South Africa through the risky, difficult and underpaid work of deep ore gold mining. These two 'movements' also faced similar exhibition/ consumption challenges with audiences being largely unreceptive to these films that were largely "made by and for an intellectual elite and not for many broad sectors of the Brazilian [South African] people" (Johnson and Stam 379). ${ }^{8}$ For example, in the case of Cinema Novo, one finds that although filmmakers criticised the existing exhibition and distribution structures, they did not successfully establish alternative means of showing their films. The response from the public on mainstream circuits was disappointing since the audience, being conditioned to watch Hollywood products, "was generally unreceptive" (Johnson and Stam 379). Exhibitors also resisted the Novo films arguing that "Cinema Novo films were too intellectual and hermetic for success in the market place" (Johnson and Stam 380). Thus, due to this lack of support, Cinema Novo filmmakers sought ways to make their films less serious and more appealing to the general public, while still maintaining their "leftist ideology" (Johnson and Stam 37).

In the case of the relatively 'serious', low budget, post-apartheid films listed above, one finds that despite such works claiming significant awards on the international festival circuit, which, in the 
case of Yesterday (Roodt, 2004), included an Oscar nomination, the local support for such works is rather poor. Therefore, as in the case of Brazil, although the 'policy of low-budget independent productions' appears to be sound, nothing can guarantee a film 'being shown [or enjoyed] in a market dominated by North American conglomerates' (Johnson and Stam 36). Furthermore, although Ster-Kinekor has provided significant support to local cinema, releasing a total number of ten films in just twelve months (September 2008 to September 2009), there has been a clear preference for comedies, given the popularity of this genre with local audiences. For example, Helen Kuun, the former local content acquisition manager for Ster Kinekor, recently announced the company's intention to support companies that 'have a proven box office success' (Screen Africa). In fact Ster Kinekor granted The Film Factory, a company that produced the 2008 hit Bakgat! (Afrikaans-language comedy), a distribution slate of three films. Kuun argued that this company was selected since it has shown that it can 'deliver and develop South African stories that appeal to the audience it is intended to reach [and] have demonstrated the passion it takes to make a film but have also considered all the business angles' (Ibid.).

The growth of the low budget comedy 'formula' is further evident in the mainstream release levels of such films, which increased from an average of six percent (2004 and 2005), to thirty-five percent (between 2006 and 2008). If one compares these levels to low-budget dramas however, one finds that such releases dropped from an average of thirty-eight percent (2004-2005) to fifteen percent (20062008). Therefore, like the low-budget filmmaking of Cinema Novo, since post-apartheid independent filmmakers have not successfully managed to establish alternative means of showing their films to national and international audiences, and the current national 
discourse of neoliberalism does not support protectionist measures, one finds that diversity has indeed declined and films have been increasingly homogenised and dictated by the market. For example, while the low-budget dramas of the earlier period included two films in Zulu (Yesterday and Faith's Corner), if one considers the later period, one finds that such films are made in English and Afrikaans and do not feature any black African languages. With the low-budget comedy trend, on the other hand, one finds that not one film in either of the periods considered above features a black African language. On the contrary, such films have been made either exclusively in English and/or [increasingly] in Afrikaans. Thus, the language preferences of the predominantly white, middle-class make-up of the market can be seen to have certain repercussions for the level of linguistic diversity in the films under discussion. Thus, in reference to the business requirements listed above, although digital technology does indeed potentially offer cost-effective production and distribution mechanisms, if film exhibition is limited to mainstream cinema circuits and such alternative platforms are not exploited, the diversity and arguably sustainability of these products may be compromised.

In addressing points three and four on Irwin's business model, one needs to question what alternative, digital, distribution mechanisms exist in post-apartheid South Africa? And how these might facilitate access to the black majority, a market that remains an 'unfulfilled' and 'underserved' populace. In terms of digital cinema screens, one finds that although the UN has recommended that small film-producing nations (less that 20 films per annum) apply alternative technologies such as digital formats to make production cheaper and to overcome pre-existing barriers in distribution (UN 98), digital cinema appears to have received far less state money than co-productions have, for example. In his presentation at a film symposium on post-apartheid 
cinema in Cape Town, ${ }^{9}$ Dearham argued that South African films are unable to gain effective release 'because of a lack of investment in domestic distribution' (oral presentation). He also noted that when market failure occurs, where films fail because of a lack of distribution infrastructure, then the state ought to step in. However, if one considers the South African context, this seems unlikely to occur since the NFVF views distribution as 'a commercial activity', and prefer to provide funds for prints, marketing and festival attendances, "but not for essential commercial distribution costs, leave the market forces to resolve it" (Ibid.). Thus, although Ster-Kinekor and $\mathrm{Nu}$ Metro have installed a number of digital screens in their respective multiplexes, and the NFVF do intend to put digital screens in the Soweto Township outside Johannesburg (NFVF c 21), the number of screens is still low when compared to other developing nations. For example, while South Africa was reported to have about 5 digital cinemas by 2005, Brazil, had 'installed 6000 low cost cinemas' by this time (DTI a 44).

There are, of course, 'small screen' alternatives for distribution. As mentioned above, home entertainment has become the biggest source of revenue in the Hollywood market. Dearham views such platforms as key to the survival of the independent filmmaker, who has the opportunity through 'three screens as it were-television, computers and mobile' to reach (sometimes niche) markets for her or his product (oral presentation). In South Africa, television is a particularly important consumption mechanism with an estimated eighty-five percent of households owning television sets (Finscope 13). Thus, this platform currently represents the most 'democratic' means of exhibiting local content. In South Africa, one finds that unlike the relationship between film and television in other African countries, these two industries are quite closely linked with M-Net, 
SABC and Etv all investing directly in feature films (Tomaselli 122). Local content has received further support from television through the Independent Communications Authority (ICASA), which has enforced local content quotas on SABC channels. The SABC is mandated by Parliament to play a role in the development of the country, in the education of its people and in the building of the South African Nation' (Fourie 149-150). However, this mandate can be seen to often contradict the demands of its commercial sponsors, who in the financial year of 2001-2002, for example, were responsible for approximately eighty-three percent of the SABC's funding. Thus, like mainstream cinema circuits the content shown on television is increasingly controlled by the demands of the market. And, although much of this content is local (due to ICASA regulations), it consists almost exclusively of soap operas, sitcoms, reality programmes and game shows, which have proven popularity with local audiences and are also relatively cheap to produce. The SABC's acquisition policy is also not the most supportive of independent cinematic production. For example, Gillis argues that if the SABC adjusted their policy and licensed content rather than commissioning it, 'this would dramatically affect the ability of filmmakers to make products for a wider audience and will improve both the variety and quality of the content' (49). This policy adjustment would also allow filmmakers to retain ownership of the material and further exploit its potential by selling it to additional television channels, virtual platforms and distributors. The mismanagement of the SABC is also a further obstacle to the realization of this platform's true potential in South Africa. For instance, in 2009 it was estimated that the national broadcaster owed companies and individuals an estimated R60 million (7 million dollars) (Screen Africa b). This has resulted in the closure of a number of local production houses and has left many 
industry workers unemployed. The mismanagement of the SABC has also interfered with the organisation's ability to implement the ICASA regulations with the local content quotas not being adhered to for the past seven years (Blignaut). Nevertheless, a new system (costing R10 million/1.5 58 million dollars) has been devised to monitor the broadcaster's compliance with its mandate to air local programmes (Ibid.). This will be introduced in April 2010 and should be far more effective than the SABC's self-monitoring service that has been used to date (Ibid.).

While post-apartheid filmmakers face a number of obstacles in the current broadcasting environment, using digital DVD technology, filmmakers might still be able to use television screens as platforms to exhibit content. Given the high-cost of cinematic release and the entry barriers to the commercial industry, making films for direct DVD release might indeed be a more cost-effective, feasible strategy in South Africa. This distribution model is related to the highly successful 'Nollywood' model of Nigeria, where ultra low-budget films are made using digital technologies. These films are produced without any state support and are released directly onto DVD with a master copy being sold by the producer to the distributor for reproduction. The films are made primarily for the vast local market. The question is whether a similar model might work in South Africa. Is the infrastructure in place and would the filmmakers, public and state support it? In terms of infrastructure, one might argue that this model would work given the high number of television sets and DVD players in the country (estimated by Finscope to be eighty-five percent and sixty-two percent respectively) (Finscope 13). With regards to filmmakers, there are a number of independent filmmakers who have adapted this model to South Africa. For example, a group from the somewhat remote 
region of Vendaland has already applied digital technology to make and distribute ultra-low budget films to their communities (TVSA). A second example of this production/distribution strategy exists in Johannesburg where three filmmakers, Batana Vundla, Charlie Vundla and Ziggy Hofmeyr, have formed a company 'Joziewood Films' following the archetype of the Nollywood model (Screen Africa c). Given the recent nature of these initiatives it is difficult to gage their success. However, it is likely that like local soap operas on television, these local products will be well received by the public if the DVDs are accessible and cheap enough for the general public to afford (see Screen Africa d for relevant Audience Rating figures).

In addition to the DVD, there are other 'small screen' digital information and communication technologies available, including the mobile phone and the Internet. Such technologies facilitate 'a new kind of relationship between place and space: through their capacity to transgress frontiers and subvert territories, they are implicated in a complex interplay of deterritorialisation and reterritorialisation' (Morley and Robins 295-6). For example, advances in mobile phone technology have allowed an increasing number of such devices to make and show video content [for example the 84 minute feature, SMS Sugarman (2008)] by South African Aryan Kaganof was the first film to be filmed entirely with a mobile phone). Secondly, the "Web has made it possible for alternative media productions of all kinds to gain greater visibility" (Jenkins 287). A local example is M-Net's African Film Library led by Dearham, which has purchased the rights to over four hundred African and South African films. This initiative was launched on the $23^{\text {rd }}$ September 2009 in partnership with DSTV Online, and is 'the largest electronic library of feature films, shorts and documentaries from 50 years of African film production' (Bizcommunity). The films on this library are to be distributed using 
cyber pay-per-view mechanisms, which Dearham views as 'the only method that the independent filmmaker has at his disposal to find his audience out there in the world, so that that audience can click on that program, pay for it using a credit card and view it (pers. comm.).

The question is whether the Internet and mobile phone technology can indeed provide a suitable economic mechanism to deliver South African content. Can such platforms effectively offer filmmakers and audiences alike innovative ways to transgress the traditional distribution and exhibition monopolies and to meet each other through alternative means? If one looks at available infrastructure one finds that although mobile phones are widespread in South Africa, with an estimated 33.9 million mobile screens, or 2.45 phones per household (Target Group Index 41), few of them have the capacity to play full-length videos, and the ones that do, are expensive to purchase. Furthermore, using such facilities to watch video content inevitably requires the user to download from the Internet. However, computer ownership in South Africa remains relatively low with approximately twenty-two percent of individuals having access to computer screens (Ibid.), and the available Internet connection being costly and slow. ${ }^{10}$ Thus, while these technologies can be considered as a part of a wider strategy, there are local limitations that hinder the current realisation of their full potential.

\section{Conclusion}

In concluding this discussion on digital cinema, I would like to caution against the presentation of digital technology as a major revolution or a 'glorious solution' to all the challenges in the postapartheid film industry. Thorburn and Jenkins warn of the trap of 'simplified models of media in transition' in which new systems of technology are believed to "displace older systems with decisive 
suddenness and have a revolutionary impact on society" (Thorburn and Jenkins $\mathrm{x}$ ). They argue that it is important in these times of technological transition to maintain "a pragmatic, historically inferred perspective that maps a sensible middle ground between the euphoria and the panic surrounding the new media" (Thorburn and Jenkins 2). This perspective should aim to "understand the place of economic, political, legal, social and cultural institutions in mediating and partly shaping the technological change" (Ibid). Thus, rather replacing the old system, it is more likely that new digital production and big/small screen distribution and exhibition models will operate parallel to existing production and distribution technology (Irwin 6). Moreover, although the first two of the aforementioned business requirements outlined above can be met with digital technology, it remains questionable whether the latter two can be fulfilled. While digital technology can potentially allow for wide, innovative forms of distribution and there is indeed an underserved black market that needs to be addressed, the current exhibition/broadcast mechanisms are not sufficient to deliver the mass of content needed to sustain an alternative narrative cinema. Therefore, although digital technology might be seen as an ideal mechanism for democratisation of cinematic production and consumption in post-apartheid South Africa, it should not be viewed as a means for independent filmmakers to make it alone. State support is still needed to maintain a diversity of product, promote the freedom of expression and ensure the sustainability and racial transformation of this developing industry. The question is whether direct, inteventionalist measures will be forthcoming given the climate of neoliberalism and the resultant conflicts in state film policy. 


\section{Notes}

1. Apartheid means "apartness" in the Afrikaans language.

2. Those oppressed under apartheid included peoples of black, Asian and mixed racial descent.

3. The Group Areas Act (No. 41) of the Apartheid government assigned different racial groups to particular residential and business locations in urban areas. The more developed metropolitan areas were reserved for whites, while the rest of the population was forced to live outside major cities in township areas.

4. In 1994, the Human Sciences Research Council (HSRC), led by academic Martin Botha, conducted a study into the restructuring of the film industry. In 1995, the Government of National Unity (GNU) established the Art and Culture Task Group (ACTAG) to counsel the Minister of Arts, Culture, Science and Technology on the formation of film policy. In 1995, following the publication of the ACTAG report, a Reference Group was appointed to draft a Film Development Strategy Document which was the basis of the 1996 White Paper on Film.

5. Leon Schuster is the most popular comedian/filmmaker in South Africa. He has been directing, writing acting, creating music and comedy skits since the 1980s and has developed a wide,supportive local audience. His films are so popular that they out sell even the biggest of the Hollywood blockbusters. Therefore, when analyzing the figures for Budget Category 5, the band that all his post-apartheid products belong to, it is important to remember that as the most successful filmmaker on the South Africa market, he can afford to make more expensive films than most local filmmakers.

6. Of the 82 films under analysis, box office and budget data was available for 37 of them. Thus, although this table does not provide data for all of the films, nor does it indicate international box office figures or DVD and broadcast sales, it does indicate some general trends of audience support at the local box office.

7. DV8 was founded by Jeremy Nathan and Joel Phiri in 2001. It is also supported by The South African Broadcasting Association (SABC) and private bodies such as Ster-Kinekor and Rand Merchant Bank in its development of digital films (NFVF 2008b: 8). DV8 has produced Shirley Adams (Hermanus, 2009), Izulu Lami (Ncayiyana, 2009), 
Zimbabwe (Roodt, 2008), Bunny Chow (John Barker, 2007), The Flyer (Revel Fox, 2005) Max and Mona (Mattera, 2005) and Forgiveness (Ian Gabriel, 2004).

8. It is important to note, however, that in addition to the substantial time gap that distinguishes these two movements (1960s - 2000s), unlike the described digital cinema trend, Cinema Novo was truly an "artistic movement". It was a gathering of artists with similar esthetic as well as political positionalities, whereas the present trend of digital cinema is fundamentally diverse in nature. It does not occur as a result of a gathering and organizing of artists - neither in present-day South Africa nor in present-day Brazil - in which a similar trend with similar difficulties now occurs.

9. Mike Dearham is an authority on South Africa, being the former head of the Non Profit Organisation the Film Resource Unit (FRU) and the current Head of Sales and the African Film Library at Mnet. He presented at the conference entitled 'South African Cinema: Creativity, Representation and Commercialism in the Post-Apartheid Film Industry' which was held at the University of Cape Town on the $30^{\text {th }}$ of May 2008. I organised it as a part of my AW Mellon PhD Fellowship and was open to public attendance. The event facilitated formal presentations and also discussions between academics, distributors, filmmakers and film publicists.

10. A high-capacity fibre optic cable, Seacom Cable linking Europe, the Middle East and Asia went live in South Africa on the $23^{\text {rd }}$ of July 2009. This can potentially have a major impact on the price and speed of the Internet connection in South Africa if the existing stakeholders in the industry allow.

\section{References}

Bakgat!. Dir. Henk Pretorious. Prod. James Carroll van Aswegen. The Film Factory. Film. 2008.

Barber, Karin. "Cultural Reconstruction in the New South Africa." African Studies Review 44.2 (2001): 177-185.

Belton, John. “Digital Cinemas: A False Revolution.” October, 100 (2002): 98-114. 
Boy Called Twist. Dir. Tim Greene. Prod. Aurelia Driver. Twisted Pictures. Film. 2004.

Bunny Chow. Dir. John Barker. Prod. Jeremy Nathan.DV8. Film.2007.

Chiken Biznis-the Whole Story. Dir. Ntshavheni Wa Luruli. Prod. Richard Green. Richard Green Productions. Film. 1998.

Danan, Martine. "National and Post-National French Cinema." Theorising National Cinema. Eds. Valentina Vitali and Paul Willemen. (London: British Film Institute. 2006): 172-185.

Dearham, Mike. “The Post-apartheid Film Industry: A Critical Analysis.” Post-apartheid Film Symposium. University of Cape Town. 31 May 2008. Oral Presentation.

Department of Trade and Industry (DTI) a. Sector Development Strategy: Film and Television. Pretoria: DTI. 2005.

Dovey, Lindiwe. "Redeeming Features: From 'Tsotsi' (1980) to 'Tsotsi' (2006)." Journal of African Cultural Studies 19.2 (2007): 143-164.

Drum. Dir. Zola Maseko. Prod. Dumisani Dlamini. Armada Pictures. Film. 2004.

DTI b. "Revised Film and Television Production Incentive." Department of Trade and Industry, 31 Mar. 2008. Web. <http://www.dti.gov.za/article/ articleview.asp?current=1\&arttypeid=1\&artid=1507>.15 Aug. 2009.

Faith's Corner. Dir. Darrell Roodt. Prod. Anant Singh. Videovision Entertainment. Film. 2005.

Finscope. 2008. “Finscope South Africa 2008." Finscope. Web. <http://www. finscope.co.za/documents/2009/brochure_SA08.pdf>. 3 Nov. 2009.

Flanery, Patrick. "What National Cinema? South African Film Cultures and the Transnational." Safundi The Journal of South African and American Studies 10.2 (2009): 239-253.

Forgiveness. Dir. Ian Gabriel.Prod. Cindy Gabriel. Giant Films. Film. 2004.

Fourie, Pieter. "The Future of Public Service Broadcasting in South Africa: the Need to Return to Basic Principles." Communicatio 29.1 and 2. (2003): 149. 
Gillis, Glen. Audience Development Report. Cape Town: Cape Film Commission. 2006.

Goldsmith, Ben and Tom O’Regan. Cinema Cities, Media Cities: The Contemporary International Studio Complex. Woolloomooloo: The Australian Film Commission, 2003.

Hayward, Susan. French National Cinema. Second Edition. London and New York: Routledge, 2005.

Human Sciences Research Council (HSRC). Survey of the South African Film and Video Industry Report. Johannesburg: HSRC, 2004.

Industrial Development Corporation. "Media and Motion Pictures Division." Web. <http://www.idc.co.za/Media\%20and\%20Motion\%20 Pictures.asp>. 11 Mar. 2010.

Irwin, James. "On Digital Cinema as a Potential Cinema Apparatus: A Marketplace Analysis." Atlantic Journal of Communication 12.4 (2004): 2-18.

Izulu Lami. Dir. Madoda Ncayiyana. Prod. Jeremy Nathan. DV8. Film. 2009.

Jenkins, Henry. “Quentin Tarantino's Star Wars? Digital Media Convergence and Participatory Culture." Rethinking Media Change: the Aesthetics of Transition. David Thorburn and Henry Jenkins. Eds. (Cambridge: MIT Press. 2004): 261-281.

Max and Mona. Dir. Teddy Mattera. Prod.Tendeka Matatu. DV8. Film. 2005.

Mbalo, Edward. "From the CEO's Desk." Inside Film South Africa 3 (2008): 3.

Mhone, Guy. "Democratisation, Economic Liberalisation and the Quest for Sustainable Development in South Africa." Governance in the New South Africa the Challenges of Globalisation. Guy Mhone and Omano Edigheji. Eds. (Cape Town: University of Cape Town Press, 2004): 18-68.

Morley, David and Kevin Robins. "Spaces of Identity: Communication Technologies and the Reconfiguration of Europe". Theorising National Cinema. Eds. Valentina Vitali and Paul Willemen. (London: British Film Institute, 2006): 295-296. 
National Film and Video Foundation (NFVF) a. South African Feature Films: 2000 to 2007. Johannesburg: NFVF. 2008.

NFVF b. Value Charter. Johannesburg: NFVF.2009.

NFVF c. Annual Report. Johannesburg: NFVF. 2007.

Saks, Lucia. "The Race for Representation." To Change Reels: Films and Film Culture in South Africa. Isabel Balseiro and Ntongela Masilela. Eds. (Detroit: Wayne State University Press. 2003):132-159.

Screen Africa a. "Film Slate Distribution." Screen Africa. 17 Sep. 2009. Web. <http://www.screenafrica.com/latest_edition/267392.htm>. 16 Mar. 2010.

Screen Africa b. “Industry Gets Tough." Screen Africa 21. 2009: 8.

Screen Africa c. "Alternative Funding Methods." Screen Africa. Web. <http:// www.screenafrica.com/events/339707.htm>. 15 Mar. 2010.

Screen Africa d. “Audience Ratings." Screen Africa 21. 2009: 50.

Seacom. "Overview." Seacom. Web < http: //www.seacom.mu/overview/ overview.html>.2 Jul. 2009.

Shirley Adams. Dir. Oliver Hermanus. Prod. Jeremy Nathan. DV8. Film. 2009.

Silinda, Moses. "Funding a Sustainable Film Industry." Inside Film South Africa 3 (Johannesburg: NFVF, 2008): 25.

Soldiers of the Rock. Dir. Norman Maake. Prod. Darren Gordon. AFDA. Film. 2005.

South Africa a. "Constitution of the Republic of South Africa 1996." South Africa. Web. <http://www.info.gov.za/documents/constitution/index. htm>. 9 Jul. 2009.

South Africa b. Group Areas Act. Number 41 of 1950. Pretoria: Office of the President. 1950.

South Africa. 2004. "Co-production Treaty - South Africa and Germany." South Africa. Web. <http://www.nfvf.co.za/document/co-productiontreaty-south-africa-and-germany>. 29 Mar. 2010.

Sparks, Allistair. Beyond The Miracle: Inside the New South Africa. Johannesburg and Cape Town: Jonathan Ball Publishers, 2003. 
Stam, Robert and Randal Johnson. Brazilian Cinema. New York: Columbia University Press. 1995.

Target Group Index. “The Little Screen.” Screen Africa 20 (2008): 41.

The Flyer. Dir. Revel Fox, Prod. Jeremy Nathan. Dv8. Film. 2005.

The Futurist. “Digital Cinema: A Breakthrough?”. The Futurist: Jul. to Aug. 2004: 9.

Thorburn, David and Henry Jenkins. Rethinking Media Change: The Aesthetics of Transition. Cambridge: MIT Press. 2004.

Tomaselli, Keyan and Ruth Teer-Tomaselli. "Exogenous and Endogenous Democracy: South African Politics and Media." Press/Politics 13. 2 (2008): 171-180.

Tomaselli, Keyan. Encountering Modernity: Twentieth Century South Africa Cinemas. Pretoria: UNISA Press, 2006.

Treffry-Goatley, Astrid. "Representation, Creativity and Commercialism in the Post-apartheid Film Industry." Kinema . Web. < http://www.kinema. uwaterloo.ca/article.php?id=453\&feature $>$. (15 Dec. 2009).

Tsotsi. Dir. Gavin Hood. Prod (local). Peter Fudacowski. Mirmax. Film. 2006.

Tuomi, Krista. Micro Economic Development Strategy (MEDS). Cape Town: Western Cape Department of Economic Development and Tourism, Film Sector, 2005.

TVSA. 2009. Vendawood. TVSA. Web. <http://www.tvsa.co.za/default. asp?blogname=special_assignment_episodes\&articleid=11482>. 25 Nov. 2009.

UCarmen eKhayelitsha. Dir. Dornford-May. Prod. Ross Garland. Dimpho Di Kopane. Film. 2005.

Ukadike, Nwachukwu Frank. "African Cinema." The Oxford Guide to Film Studies. John Hill and Pamela Church Gibson. Eds. (Oxford: Oxford University Press. 1998): 569-577.

United Nations. Development Report: Cultural Liberty in Today's Diverse World. New York: United Nations Development Programme, 2004. 
Yesterday. Dir. Darrell Roodt. Prod. Anant Singh. Videovision Entertaintment. Film. 2004

Zimbabwe. Dir. Darrell Roodt. Prod. Jeremy Nathan. DV8. Film. 2008.

[Received in 27/04/2011. Approved in 17/10/2011] 
